\title{
Level of mRNA Insulin Gene and Blood Glucose STZ-Induced Diabetic Rat are Improved by Glucomannan of Amorphophallus muelleri Blume from East Java Forest Indonesia
}

\author{
Fatchiyah Fatchiyah ${ }^{1,2}$, Damai Aulia Nurmasari ${ }^{1}$, Nuri Masruro ${ }^{1}$, Rista Nikmatu Rohmah ${ }^{1,3}$, \\ Lidwina Faraline Triprisila ${ }^{1,3}$, Mulyati Mulyati ${ }^{4}$, Takahisa Yamada ${ }^{5}$, Takeshi Ohta ${ }^{6}$ \\ ${ }^{1}$ Research Center of Smart Molecule of Natural Genetic Resources, Brawijaya University, Malang 65145, \\ Indonesia \\ ${ }^{2}$ Department of Biology, Faculty of Mathematics and Natural Sciences, Brawijaya University, Malang 65145, \\ Indonesia \\ ${ }^{3}$ Biosains Institute, Brawijaya University, Malang 65145, Indonesia \\ ${ }^{4}$ Faculty of Biology, Gadjah Mada University, Yogyakarta 55281, Indonesia \\ ${ }^{5}$ Laboratory of Animal Genetics Graduate School of Science and Technology, Niigata University, Niigata \\ 9502181, Japan \\ ${ }^{6}$ Graduate school of Agriculture, Kyoto University, Kyoto 6068501, Japan
}

Article history:

Submission January 2019

Revised February 2019

Accepted March 2019

*Corresponding author:

E-mail:

fatchiya@ub.ac.id

\begin{abstract}
Diabetes mellitus is one of metabolic disorder with high level of blood sugar glucose and reduces pancreatic-insulin levels that are altered by unhealthy food and lifestyle. To manage the blood glucose and insulin level, we need the diabetes dietary management related with insulin gene cascade. The purpose of this study was to investigate the influence glucomannan fiber to mRNA level of the insulin gene and genes cascade expression of target cells of type 1 diabetic rat. Threemonth-old male (Rattus norvegicus strain Wistar) were fed with fiber of glucomannan of Amorphophallus muelleri Blume with dosage $0,06 \mathrm{~g} / \mathrm{kg} \mathrm{BW}$ and $0.12 \mathrm{~g} / \mathrm{kg}$ BW every day during one month. RNA dot blotting with specific cDNA probe was performed mRNA level of insulin gene. The result of this study showed that glucomannan could reduce of body weight and blood glucose level significantly. The mRNA level of insulin gene of diabetic rats-treated $0.12 \mathrm{~g} / \mathrm{kg}$ BW glucomannan fiber dosage was the highest significance level among of all groups. In histopathological analysis, glucomannan was increasing significantly in IRS-1 level expression proliferate properly and consistently increasing of the PI3-K expression level in treated diabetic rats. This study indicates that the $0.12 \mathrm{~g} / \mathrm{kg} \mathrm{BW}$ glucomannan was optimum dosage that effectively as role for alternative highfiber therapy of type 1 diabetic through insulin receptor tyrosine kinase pathway.
\end{abstract}

Keywords: Beta pancreatic cells, glucomannan, mRNA of insulin gene, stzinduced diabetic rat

\section{Introduction}

Diabetes mellitus (DM) is a chronic disease caused by production deficiency of insulin in pancreas or ineffectiveness of the insulin production [1]. According to the World Health Organization (WHO), the prevalence of DM in Indonesia can realize 213 million people until 2030 [2]. The one of cause of diabetes related with life style and diet- ary habits is unhealthy consumption that can raise blood sugar rapidly and elevate the risk development of diabetes $[1,3]$.

Insulin is a hormone produced by pancreatic beta cells that requires signaling pathways involving different types of proteins [4]. One type of protein that plays a role in the signaling pathway is Insulin Receptor Substrate 1 (IRS-1) and Phos-

\section{How to cite:}

Fatchiyah F, Nurmasari DA, Masruro N et al. (2019) Level of mRNA Insulin Gene and Blood Glucose STZ-Induced Diabetic Rat are Improved by Glucomannan of Amorphophallus muelleri Blume from East Java Forest Indonesia. Journal of Tropical Life Science 9 (2): 163 - 169. doi: 10.11594/jtls.09.02.05 
phoinositide 3-kinases (PI3Ks). The insulin bond at the receptor will induce a conformational change that results in the phosphorylation of a number of tyrosine residues in IRS proteins. Phosphorylation of the IRS 1 results in secondary signals connecting the insulin receptor to trans-membrane glucose transport $[4,5]$.

Healthy nutrition is important for optimum health, growth and development and can work for disease defenses. Amorphopallus sp. is Araceae plant family that grows well in tropical regions, mostly in Asia. The glucomannan structure has glucose and mannose ratio $1: 6$ with a polymer form that was exposed by X-ray [6, 7]. Moreover, the glucomannan was reported that indices alleviate constipation, reduces intestinal flora, lowers blood sugar and cholesterol and may possibly promote weight loss and inhibit metabolic and degenerative disease [8, 9]. A lot of research reports the glucomannan function, but the mechanism pathway of dietary fiber of glucomannan (Amorphophallus muelleri Blume) controlling the diabetes disease is still unclear.

This study has focused to observe the level of blood glucose, mRNA of insulin gene, insulin receptor substrate- 1 expression, regenerating the pancreatic beta-cells and hepatocyte cells of PI3K expression of STZ-induced diabetic rat provide by a glucomannan fiber of $A$. muelleri Blume, original local plant from East Java forest, at Indonesia. We predict that this glucomannan fiber can reduce the risk of developing diabetes. The implication may have therapeutic benefit to control the blood glucose, regulate the insulin gene metabolism and improve the normal pancreatic $\beta$-cells regeneration in diabetic metabolic conditions.

\section{Material and Methods \\ Experimental animals}

Twenty male Wistar rats (Rattus novergicus alvinus, Rodent, Mammalia) taken from animal centre of LPPM-UGM Yogyakarta, $\pm 150 \mathrm{~g}, 3$ months old were divided into 4 groups: (1) three rats of wild type (WT) and non-treatment, (2) three diabetic rat-induced streptozotocin (STZ) and non-treatment (3) three diabetic rat-induced streptozotocin (STZ) and treated by $0.06 \mathrm{~g} / \mathrm{kg}$ body weight of glucomannan fiber, and (4) three diabetic rat-induced streptozotocin (STZ) and treated by $0.12 \mathrm{~g} / \mathrm{kg}$ BW of glucomannan fiber. The diabetic rats were obtained with single dosage of
Streptozotocin (50 mg/kgBW) (SIGMA- Aldrich) intraperitoneally.

The fiber of glucomannan was extracted from dried tuber of $A$. muelleri Blume. Each of rat of group 3 and 4 were feeding orally with dosage $0.06 \mathrm{~g} / \mathrm{kgBW}$ and $0.12 \mathrm{~g} / \mathrm{kg}$ BW glucomannan fibers every day during a month. The blood glucose level was tested before STZ-injection, four days after injection and continued interval four days until the end of treatment. The all-experimental animals were handling in the morning every day. Ethical Clearance of Brawijaya University Research Ethics Committee has approved this research study.

\section{Histopathology and immunofluorescence analy- sis}

The observations of $\beta$-pancreatic cells-damaged, $\beta$-pancreatic normal cells-regenerated, and hepatocyte cells were performed from tissue paraffin embedding [10]. The histological slides were examined by immunofluorescence.

Histological immunofluorescence staining slides were conducted to determine the IRS-1 expression on $\beta$-pancreatic cells and PI3K expression in hepatocyte cells. The slides were stained with primary anti-IRS-1 rabbit polyclonal-IgG (1 : 1500 dilution; Santa Cruz Biotech, INC) antibody, antibody of rabbit polyclonal to PI-3-K p85 alpha + gamma (1 : 1500 dilution; Abcam, Hong Kong) and all slides were counter-stained with secondary antibody mouse anti-rabbit IgG-FITC.

To visualize and measure the IRS- 1 and PI3K expressions was analyzed using the Flowview FV3000-Olympus Confocal Laser Scanning Microscopy. Slides were captured on five microscope fields. The IRS-1 and PI3K expression was quantified with the Olympus FluoView ver 1.7a software and calculated the expression for all groups $(\mathrm{P}<0.05)$.

\section{CDNA of pro-insulin gene probe synthesis}

Rat's pancreatic tissues total RNA isolation was performed by using QuickPrepTM Total RNA Extraction Kit (Amersham). Analysis of insulin gene mRNA was performed by RNA dot blotting with cDNA probe of insulin gene. CDNA probe was synthesized from total RNA non-diabetic rat and constructed by reverse transcriptionPCR of Ready-To-GoTM RT-PCR Beads (Amersham). RT-PCR analysis was done by Takara Gra- 
dients PCR and amplified using the specific primer of insulin gene, F-INS34 5'-ATTGTTCCAACATGGCCCTA-3' and R-INS333 5'TGCAGCCAACCAGATACTTG-3'. The cDNA purified by the RNA purification kit (IllustraTM GE Healthcare, Amersham). The cDNA probe of pro-insulin gene is labelled with biotin-nick translation mix (Roche).

\section{Measuring mRNA level analyzed by Northern blot}

Level of mRNA pro-insulin gene of each sample was analysed by Northern blotting using Nylon membranes HybondTM GE healthcare (Amersham)-N-mounted into dot-blotter (Bio-Rad). One $\mu \mathrm{l}$ of mRNA of all samples was applied to the dotblotter, signed by cDNA probe of pro-insulin gene-biotin-labelled, performed using Streptavidin-horseradish peroxidase (SA-HRP) and visualized by amino ethyl carbazole (AEC) substrates. Membranes-mRNA-cDNA probe-labeled was measured the transcriptional level of pro-insulin gene by ChemiDoc Gel Imaging (Bio-Rad) and counted the intensity by Quantity-One software, $(\mathrm{P}<0.05)$.

\section{Statistical analysis}

Data analysis results were expressed as means. The data was variance analyzed (ANOVA) statistically with SPSS 16.0 software (SPSS Inc., Chicago, Illinois, USA). The differences effect and interaction among treatments were considered significant when $\mathrm{P} \leq 0.05$ and then followed up by Tukey test.

\section{Results and Discussion \\ Body weight, blood glucose level and mRNA level of insulin gene}

Body weight of wild type rat groups overall had higher body weight gaining than the diabetic rat group (Table 1), but it was not significant with each other $(\mathrm{P}<0.05)$. Likewise, the body weight gaining of diabetic rat treated glucomannan, both $\mathrm{DM}+0.06 \mathrm{~g} / \mathrm{kg} \mathrm{BW}$ and $\mathrm{DM}+0.12 \mathrm{~g} / \mathrm{kg} \mathrm{BW}$ glucomannan is higher than diabetic rat group. Whereas, DM+0.12 g/kg BW glucomannan rat group showed the increasing of weight gaining than $0.06 \mathrm{~g} / \mathrm{kg}$ BW glucomannan rat group.

The glucomannan fiber is a soluble fiber has investigated impact on plasma lipids, body weight, fasting blood glucose and blood pressure [11]. The body weight, levels of serum triglycerides (TG) and total cholesterol (TC) in mature male diabetic rats fed a high-fat diet (HFD) were increasing significantly [12, 13]. According to Yoshida et al. (2006), glucomannan diet in diabetic subjects were reduction body weight, abdominal fat accumulation and inhibition lipid absorption [11, 9]. Recent study report that body weight decreases relatively after glucomannan feeding in diabetic rat group. The glucomannan role as a soluble fiber has investigated impact on plasma lipids, body weight, fasting blood glucose and blood pressure [11]. The body weight, levels of serum triglycerides (TG) and total cholesterol (TC) in mature male diabetic rats fed a high-fat diet (HFD) were increasing significantly $[12,13]$ According to Yoshida et al. (2006), glucomannan diet in diabetic subjects were reduction body weight, abdominal fat accumulation and inhibition lipid absorption $[11,9]$.

The blood glucose level of diabetic ratstreated with $0.12 \mathrm{~g} / \mathrm{kg}$ BW glucomannan fiber dosage was significantly lower than both diabetic rats and rats treated with $0.6 \mathrm{~g} / \mathrm{kg}$ BW glucomannan fiber $(\mathrm{P}<0.05)$ (Table 1). Meanwhile, diabetic rat group, DM and DM+0.06 g/Kg BW both showed that the high level significantly compared to all groups. In addition, DM+0.12 g/kg BW glucomannan group showed decreasing of blood glucose level which is have closed with WT group. Meanwhile, the wild type was treated with $0.6 \mathrm{~g} / \mathrm{kg}$ BW and $0.12 \mathrm{~g} / \mathrm{kg}$ BW glucomannan not show different significantly compared with the wild type group. The insulin level of diabetic rats-treated $0.12 \mathrm{~g} / \mathrm{kg}$ BW glucomannan fiber dosage was highest level expression significantly among of both diabetic rat (Table 1). However, the insulin level expression in WT rats-treated $0.06 \mathrm{~g} / \mathrm{kg} \mathrm{BW}$ glucomannan fiber was the higher level than both of diabetic and WT rat group.

The dietary glucomannan also reported increasing gradual absorption of dietary sugar and decreasing of blood glucose level. According to Chandalia et al. 2000, glucomannan that contains soluble fiber can control the glycemic level and decreased hyperinsulinemia [9, 11]. Supplement of glucomannan also reported has beneficial effects to lower blood glucose and cholesterol with daily dosage of glucomannan $0.7 \mathrm{~g} \mathrm{KGM} / 100 \mathrm{kcal}$ intake [15]. From this research, the level of blood glucose is decreasing in rats-treated with $0.12 \mathrm{~g} / \mathrm{kg}$ 
Table 1. Body weight, blood glucose level and mRNA level intensity of the insulin gene of wild type and diabetic rat group

\begin{tabular}{lcccccc}
\hline $\begin{array}{l}\text { Biological } \\
\text { parameters }\end{array}$ & WT & $\begin{array}{c}\text { WT+0.06g/ } \\
\mathrm{kg} \mathrm{BW}\end{array}$ & $\begin{array}{c}\mathrm{WT}+0.12 \mathrm{~g} / \\
\mathrm{kg} \mathrm{BW}\end{array}$ & $\mathrm{DM}$ & $\begin{array}{c}\mathrm{DM}+0.06 \mathrm{~g} / \mathrm{k} \\
\mathrm{g} \mathrm{BW}\end{array}$ & $\begin{array}{c}\mathrm{DM}+0.12 \mathrm{~g} / \\
\mathrm{kg} \text { BW }\end{array}$ \\
\hline Body weight & $210 \pm 5.1$ & $230 \pm 22.9$ & $225 \pm 13.23$ & $200 \pm 13.0$ & $207 \pm 3.6$ & $221.3 \pm 14.8$ \\
\hline $\begin{array}{l}\text { Blood } \\
\text { Glucose }\end{array}$ & $123.8 \pm 19.8^{*}$ & $126.1 \pm 18.8$ & $127.2 \pm 18.1$ & $274.4 \pm 9.4^{* *}$ & $300 \pm 10.4^{* *}$ & $124.9 \pm 8.2^{*}$ \\
\hline Insulin level & $1.0 \pm 5.0$ & $3.1 \pm 9.3^{* *}$ & $1.9 \pm 2.8$ & $0.51 \pm 1.6$ & $0.56 \pm 2.8$ & $0.96 \pm 2.8^{*}$ \\
\hline
\end{tabular}

The data represent means \pm standard deviation. $\mathrm{P}<0.05$. The blood glucose level was higher significantly of rat groups $(*)$, and highest among of all groups $(* *)$ of wild type and diabetic rat.
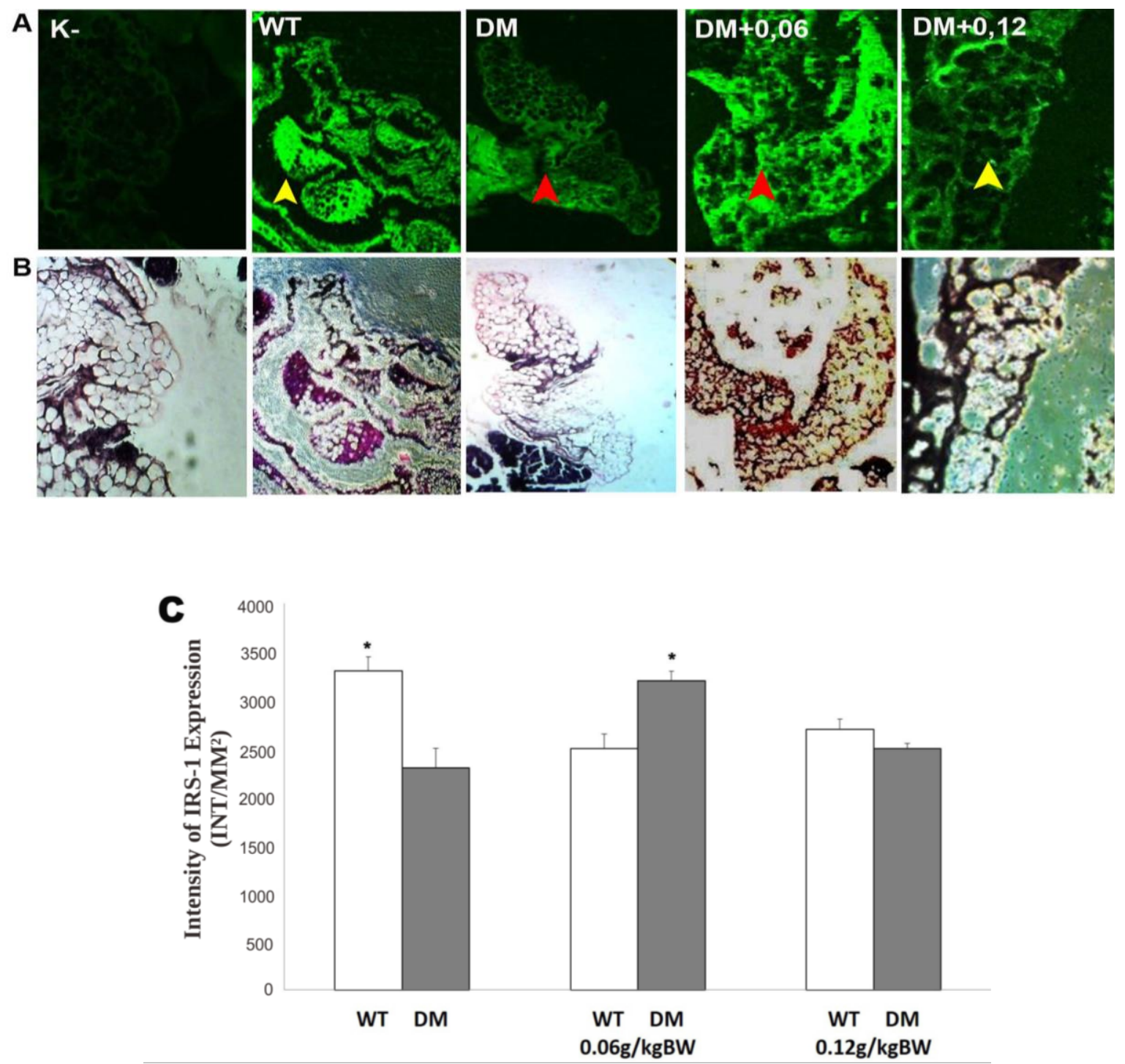

Figure 1. The IRS-1 expression level of WT and STZ-induced diabetic rats in pancreatic tissues were exposing by Confocal Laser Scanning Microscopy (200× magnification). A) The IRS-1 expression was exposed by FITC staining and Flowview FV1000 CLSM, B) the target pancreatic tissue structure checked by HE staining, and C) IRS-1 level expression based on CLSM data-photos. The intensities of IRS-1-FITC quantified by the Olympus FluoView software (ver 1.7a) of CLSM $(\mathrm{P}<0.05)$. The yellow head arrow is normal pancreatic $\beta$-cells. The red head arrow is a destructive pancreatic $\beta$ - cell. *= Significantly different. 


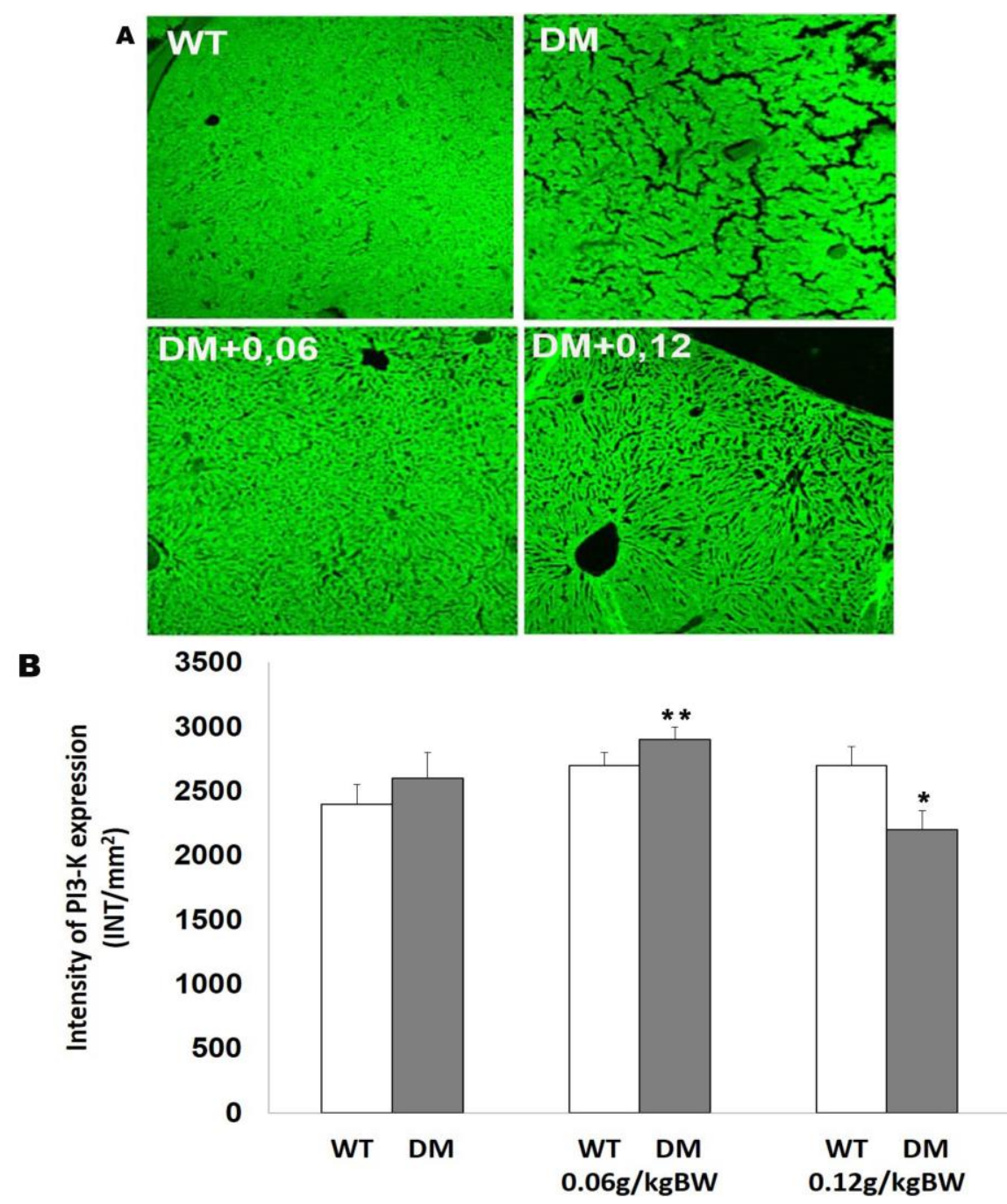

Figure 2. The expression level of PI3-K in hepatocyte cells of WT and STZ-induced diabetic rats were exposed by Confocal Laser Scanning Microscopy (200× magnificent), A) FITC Staining, B) C) PI3-K level expression. Intensities of PI3-K-FITC were quantified by the Olympus Fluoview software (ver 1.7a) of CLSM $(\mathrm{P}<0.05) .{ }^{*}=$ lower significantly different, ${ }^{* *}=$ high significantly different.

BW fiber dosage. Vice versa, the $0.06 \mathrm{~g} / \mathrm{kg}$ BW glucomannan fiber dosage show the increasing of blood glucose.

\section{Histopathology and immunofluorescence analy- sis}

The pancreatic $\beta$-cells pancreas and low IRS1 expression compared with the wild type group (Figure 2A). After treated by $0.12 \mathrm{~g} / \mathrm{kg} \mathrm{BW}$ glucomannan fiber, the pancreatic $\beta$-cells of STZ--induced diabetic rats are proliferated as properly.

In addition, the IRS- 1 expression in DM+0.06 g/kg BW glucomannan group was increased significantly $(\mathrm{P}<0.05)$ compared with $\mathrm{DM}+0.12$ $\mathrm{g} / \mathrm{kg}$ BW glucomannan group also DM group, as shown Figure 2B. This result also showed that the expression of PI3-K in DM+0.06 g/kg BW glucomannan group is higher than $0.12 \mathrm{~g} / \mathrm{kg}$ BW diabetic rats, DM group and the normal rat group significantly.

Diabetes mellitus (DM) is caused by dysfunction of pancreatic $\beta$-cells and the progressive failure of insulin secretion. Our study revealed that the mRNA level of insulin gene of diabetic ratstreated $0.12 \mathrm{~g} / \mathrm{kg} \mathrm{BW}$ was significantly higher than both DM and DM treated $0.6 \mathrm{~g} / \mathrm{kg}$ group. The increasing of mRNA level of insulin gene is expected have a capability to induce the activating protein related to pancreatic $\beta$ cells repairing. It was showed the pancreatic cells were improved as proper in immuno-histological fluorescence data after treated by $0.12 \mathrm{~g} / \mathrm{kg}$ BW glucomannan fiber. 
This data is consistent with a study conducted by Shah et al. 2015, the pancreatic $\beta$-cell activation caused by insulin mRNA level increasing [16].

Furthermore, we observed the expression of IRS-1 and PI3-K play a role as mediating insulin's metabolic effects. According to Wang (2009), the degradation of IRS-1 can affect insulin resistance observed in TH mice [17]. The reduction of IRS-1 activation could induce mutation of tyrosine kinase hINSR gene on diabetic mellitus patient that cause insulin signaling defect [18]. PI3K signaling pathway plays an important role in regulating expression and activation of IRS 1/2, GLUT4, PPAR- $\gamma$, PI3K and AKT to increase insulin stimulated GLUT4 translocation [19-21].

Based on our result, the glucomannan fiber can increase the level expression of IRS-1 and PI3-K indicating that it could possibly prevent insulin resistance in rat diabetics.

\section{Conclusion}

This study concludes that dietary glucomannan with dosage of $0.12 \mathrm{~g} / \mathrm{kg}$ BW effectively control the blood sugar level and regenerate the betacells pancreas of diabetic rat via receptor tyrosine kinase pathway. Glucomannan could be a promising nutritional alternative for reducing the risk of developing diabetes.

\section{Acknowledgment}

This study was supported by Brawijaya World Class University Program research grant and Stranas DDGE Ministry of Higher Education Republic Indonesia.

\section{References}

1. Hsu I R, Kim SP, Kabir M, Bergman RN (2007) Metabolic syndrome, hyperinsulinemia and cancer. American Journal of Clinical Nutrition 86 (3): 867 - 871. doi: 10.1093/ajcn/86.3.867S.

2. World Health Organization (WHO) 2017 Diabetes 15. In Diabetes (Vol. 2014, p. http://www.who.int/mediacentre/factsheets/fs312/en). Accessed date: September 2017.

3. Gavin JR (2001) Pathophysiologic mechanisms of postprandial hyperglycemia. The American Journal of Cardiology 88 (6): 4 - 8. doi: 10.1016/S00029149(01)01830-6.

4. Pollock RF, Erny-Albrecht KM, Kalsekar A et al. (2011) Longacting insulin analogs: a review of "real-world” effectiveness in patients with type 2 diabetes. Current Diabetes Reviews 7 (1): 61 - 74. doi: 10.2174/157339911794273892

5. Boucher J, Kleinridders A, Kahn, CR (2014) Insulin receptor signaling in normal and insulin resistant. Cold Spring Harbor
Perspectives in Biology 6: a009191. doi: 10.1101/cshperspect.a009191

6. Khanna S, Tester RF (2006) Influence of purified konjac glucomannan on the gelatinisation and retrogradation properties of maize and potato starches. Food Hydrocolloids 20: 567-576. doi: 10.1016/j.foodhyd.2005.05.004

7. Katsuraya K, Okuyama K, Hatanaka K et al. (2003) Constitution of konjac glucomannan: Chemical analysis and 13C NMR spectroscopy. Carbohydrate Polymers 53 (2): 183-189. doi: 10.1016/S0144-8617(03)00039-0

8. Chandalia M, Garg A, Lutjohann D et al. (2000) Beneficial effects of high dietary fiber intake in patients with type 2 diabetes mellitus. New England Journal of Medicine 342 (19): 13921398. doi: 10.1056/NEJM200005113421903.

9. Yoshida M, Vanstone CA, Parsons WD et al. (2006) Effect of plant sterols and glucomannan on lipids in individuals with and without type II diabetes. European Journal of Clinical Nutrition 60: 529 - 537. doi: 10.1038/ sj.ejcn.1602347.

10. Fatchiyah F, Zubair M, Shima Y et al. (2006) Differential gene dosage effects of Ad4BP/SF-1 on target tissue development 341 (4): 1036 - 1045. doi: 10.1016/j.bbrc.2006.01.058

11. Aoe S, Kudo H, Sakurai, S (2015) Effects of liquid konjac on parameters related to obesity in diet-induced obese mice. Bioscience, Biotechnology and Biochemistry 79 (7): 1141 - 1146. doi: 10.1080/09168451.2015.1018119

12. Morinaga H, Ohta T, Matsui K et al. (2009) Effect of food restriction on adipose tissue in spontaneously diabetic torii fatty rats. Experimental Diabetes Research 2009: 715057. doi: 10. 1155/2009 /715057.

13. Ohta T, Toriniwa Y, Ryumon N et al. (2017) Maternal high-fat diet promotes onset of diabetes in rat offspring. Animal Science Journal 149-155. doi: 10.1111/asj.12606.

14. Miyajima K, Teoh SH, Yamashiro H et al. (2018) Effects on glycemic control in impaired wound healing in spontaneously Diabetic Torii (SDT) fatty rats. Medical Archives 72 (1): 4-8. doi: 10.5455/medarh.2018.72.4-8.

15. Fang W, Wu P (2004) Variations of konjac glucomannan (KGM) from Amorphophallus konjac and its refined powder in China. Food Hydrocolloids 18 (1): 167 - 170. doi: 10.1016/S0268-005X(03)00044-4.

16. Shah AD, Langenberg C, Rapsomaniki E et al. (2015) Type 2 diabetes and incidence of cardiovascular diseases: A cohort study in 1.9 million people. The Lancet Diabetes \& Endocrinology 3 (2): 105 - 113. doi: 10.1016/ S2213-8587(14)70219-0.

17. Wang CH, Lai P, Chen ME, Chen HL (2008) Antioxidative capacity produced by Bifidobacterium- and Lactobacillus acidophilus-mediated fermentations of konjac glucomannan and glucomannan oligosaccharides. Journal of the Science of Food and Agriculture 88 (7): 1294 - 1300. doi: 10.1002/jsfa.3226.

18. Fatchiyah F, Christian N, Soeatmadji D (2013) Reducing IRS-1 activation cause mutation of tyrosine kinase domain hINSR 
gene on type-2 diabetes mellitus patients. Bioinformation 9 (17): $853-857$.

19. Kong W, Zhang H, Song D et al. (2009) Berberine reduces insulin resistance through protein kinase $\mathrm{C}$ - dependent up-regulation of insulin receptor expression. Metabolism 58 (1): 109119. doi: 10. 1016/j. metabol. 2008.08.013
20. Saltiel AR, Kahn CR (2001) Insulin signaling and the regulation of glucose and lipid metabolism. Nature 414 (6865): 799 - 806. doi: 10.1038/414799a

21. Martin S, Millar CA, Lyttle CT et al. (2000) Effects of insulin on intracellular GLUT4 vesicles in adipocytes: Evidence for a secretory mode of regulation. Journal of Cell Science 113: 3427 - 3438. doi: 10.1074/jbc.270.50.3019. 
This page is intentionally left blank. 